\title{
Precocious puberty: Pathology, related risks, and support strategies
}

\author{
Linda Synovitz , Joanne Chopak-Foss \\ Southeastern Louisiana University, Hammond, USA; ${ }^{*}$ Corresponding Author: lsynovitz@selu.edu
}

Received 9 September 2013; revised 11 October 2013; accepted 3 November 2013

Copyright (c) 2013 Linda Synovitz, Joanne Chopak-Foss. This is an open access article distributed under the Creative Commons Attribution License, which permits unrestricted use, distribution, and reproduction in any medium, provided the original work is properly cited.

\begin{abstract}
Children are currently starting pubertal development much earlier than 20 to 30 years ago. Data from the National Health and Nutrition Examination Survey (NHANES III) conducted from 1988-1994 revealed that the median age for breast development in white girls was approximately 9.7 years and 8 years in African-American girls versus 10.9 years ago. More recent data, however, indicate that some children are starting pubertal development even earlier (age 7 or 8 in girls or age 9 in boys). Very early pubertal development is identified as precocious puberty, a phenomenon that brings great concern to others besides parents: the child, their peers, school nurses, teachers and counselors. This paper discusses precocious pubertal development, possible causes or relationships, related risks, treatment and helping strategies.
\end{abstract}

Keywords: Precocious Puberty; Early Sexual Maturity; Puberty; Pubertal Development

\section{INTRODUCTION}

Children are currently starting pubertal development much earlier than 20 to 30 years ago [1]. Very early pubertal development is identified as precocious puberty [2-4]. Parents of these children must often be perplexed and left wondering how to cope with this phenomenon. This paper discusses pubertal development, possible causes, related risks, treatment and helping strategies.

\section{PUBERTAL DEVELOPMENT}

Pubertal development includes rapid growth of bones and muscles, changes in body shape and size, and development of the body's ability to reproduce. Marshall and Tanner [5,6] began documenting pubertal development more than forty years ago and identified five stages of pubertal development and physical elements of sexual maturity in boys (size of the testes, length of penis, pubic hair) and girls (breast and pubic hair development). Subsequently, the well-cited Tanner scales $[5,6]$ were developed in which they chronicle normal pubertal development. Please see Table 1 Tanner scale for girls and Table 2, Tanner scale for boys.

The 1997 Pediatric Research in Office Settings (PROS) network study documented pubertal development [7]. Researchers found that the age of pubertal development may differ by race and country, but usually begins to take place in girls between ages 8 and 16 and in boys between ages 9 and 14. On average, African-American girls showed signs of puberty almost two years sooner than white girls [7], and by age 8 , nearly 50 percent of the black girls but only 15 percent of the white girls were reported to have begun pubertal development. See Table 3 for differences. The National Health Examination Surveys (NHES I, II, III) administered by the Centers for Disease Control and Prevention (CDC) also documented pubertal development of children 6 to 11 years and 12 to 17 years and found similar results [8]. Biro et al. [9], however, found that signs of puberty are being observed in children as young as ages 7 and 8 years. The researchers [9] assessed the maturation level of 1239 girls at three sites across the United States. Results revealed differences among age, race/ethnicity, body mass index (BMI) percentile and site. Even among white girls, the proportion at ages 7 and 8 years who had breast development greater or equal to Stage Two of the Tanner scale was greater than results reported 20 years ago [9].

The following section describes two known types of precocious puberty, Central and Peripheral precocious puberty. It is important to differentiate between them because the cause and the course of treatment differ depending on the type. 
Table 1. Tanner scale-girls (edited).

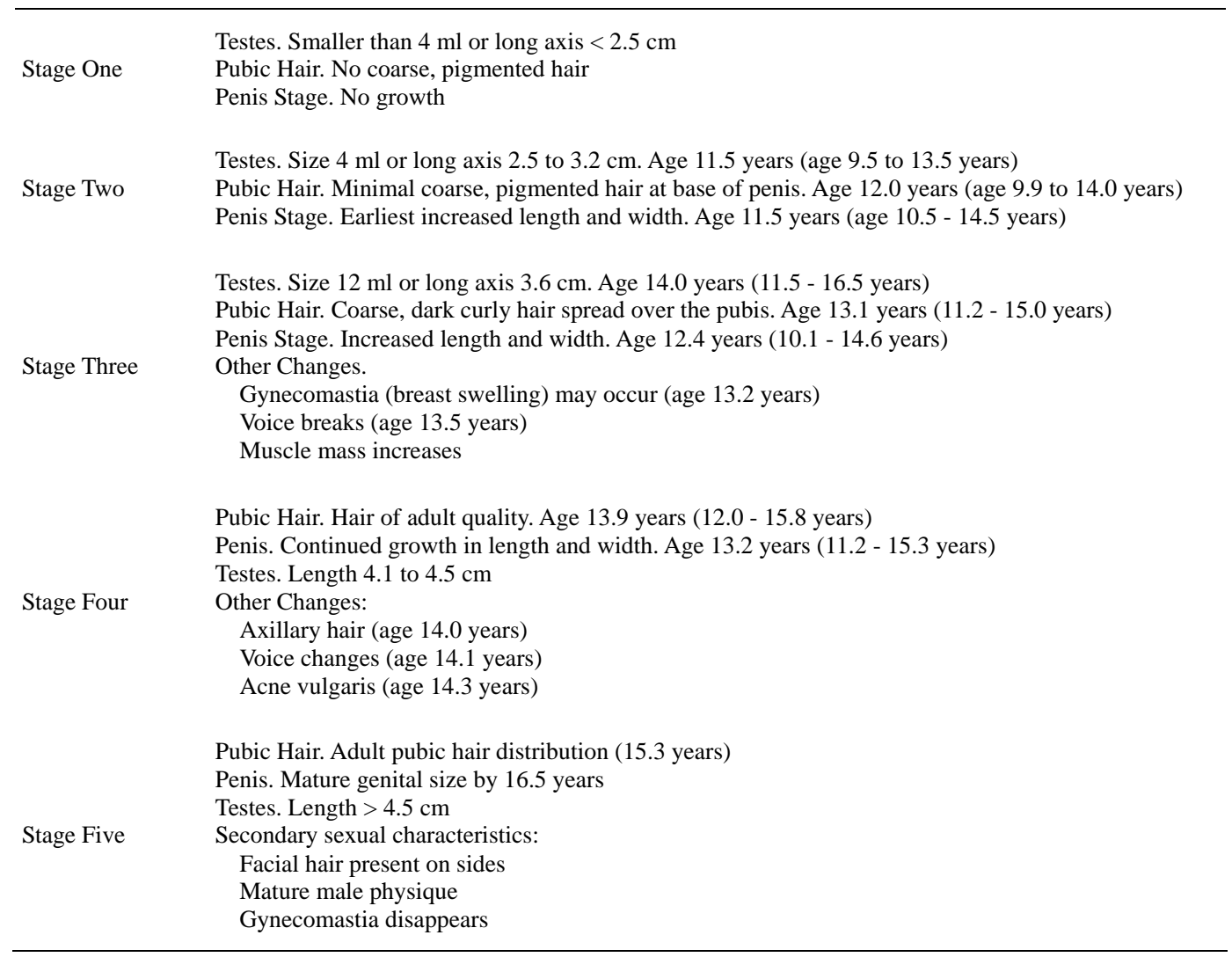

Table 2. Tanner scale in boys (edited).

\begin{tabular}{|c|c|c|}
\hline Tanner Stage & Pubic Hair & Breasts \\
\hline 1 & None & Papilla elevation \\
\hline 2 & $\begin{array}{l}\text { Minimal coarse, pigmented hair mainly on } \\
\text { labia. Age: } 11.2 \text { years ( } 9.0 \text { - } 13.4 \text { years })\end{array}$ & $\begin{array}{l}\text { Small breast buds palpable and areolae enlarge. } \\
\text { Age: } 10.9 \text { years ( } 8.9 \text { - } 12.9 \text { years })\end{array}$ \\
\hline 3 & $\begin{array}{l}\text { Darker, begins to curl. Age: } 11.9 \text { years } \\
\text { (9.6 - } 14.1 \text { years })\end{array}$ & $\begin{array}{c}\text { Elevation of breast contour; areolae enlarge. } \\
\text { Age: } 11.9 \text { years ( } 9.9 \text { - } 13.9 \text { years })\end{array}$ \\
\hline 4 & $\begin{array}{l}\text { Coarse, less curly than adult. Adult quality. } \\
\text { No spread to junction of medial thigh with } \\
\text { perineum. Age: } 12.6 \text { years (10.4 - } 14.8 \text { years) }\end{array}$ & $\begin{array}{c}\text { Areolae forms secondary mound on the breast. } \\
\text { Age: } 12.9 \text { years (10.5 - } 15.3 \text { years) }\end{array}$ \\
\hline 5 & $\begin{array}{l}\text { Adult triangle. Adult distribution of hair. } \\
\text { Pubic hair spreads to medial thigh. }\end{array}$ & $\begin{array}{l}\text { Mature; nipple projects. Adult breast contour. } \\
\text { Areola recesses to general contour of breast. }\end{array}$ \\
\hline
\end{tabular}

\section{DIFFERENTIATING CENTRAL AND PERIPHERAL PRECOCIOUS PUBERTY}

\subsection{Central Precocious Puberty (CPP) and Causes}

The more common form of precocious puberty is central precocious puberty (CPP) wherein the entire hypothalamic-pituitary-gonadal axis (HPG axis) simply starts too soon $[3-5,10]$. As a result, very young girls may experience bodily signs of pubertal development and even menstruation.

\subsection{Peripheral Precocious Puberty (PPB) and Causes}

The second form is peripheral precocious puberty (PPB). In PPB, GnRH is not a factor. PPB could be due to a myriad of reasons because of ovarian cysts or other diseases of the ovaries, testicles, adrenal glands or pituitary gland [11]. In boys, gene mutation, a rare disorder, could also be a cause [12]. 
Table 3. Differences between white and African-American girls.

\begin{tabular}{|c|c|}
\hline White Girls & African-American Girls \\
\hline Breast Development beginning age & Breast Development beginning age \\
\hline 9.11 years $\left(4^{\text {th }}\right.$ grade $)$ & 8.5 years ( $3^{\text {rd }}$ grade) \\
\hline By age $10.5 / 11$, many are in stage II breast development & By age $9,62 \%$ are in stage II breast development \\
\hline Pubic Hair. 10.6 average age & $\begin{array}{l}\text { Pubic Hair. } 8.9 \text { years, } \\
34 \% \text { of girls have pubic hair }\end{array}$ \\
\hline Axillary Hair. 10 - 11 average hair & Axillary Hair. 10 - 11 average hair \\
\hline Overall average age of onset of puberty is age 9 & Overall average age of onset of puberty is age 8 \\
\hline
\end{tabular}

\section{POSSIBLE CAUSES OF PRECOCIOUS PUBERTY}

\subsection{Medical Causes}

For the majority of children of both genders, there is no underlying medical problem and no reason that can be identified for the HPG axis to begin when it did [13]. For some children, there are several known medical causes, albeit many of them are rare. Brain or spinal cord tumor or injury, hypothyroidism, congenital diseases of the adrenal glands, bone genetic disease called McCune-Albright syndrome and radiation of the brain or spinal cord have been reported as causes [12]. Slyper [14] reports that the cause of early maturation could be due to hyperinsulinaemia (high insulin levels in the blood) and insulin resistance. Kaplowitz [2,3] also reported an infection, such as encephalitis or meningitis, could be a cause of CPP. Because of these findings, some physicians order MRI tests on 6 - 8 year old girls who show signs of early puberty.

\subsection{Genetics}

A genetic component may be linked to early pubertal development. A study from Israel estimated that in one fourth of cases, precocious puberty was familial [15]. If there is a history of early puberty in a parent or sibling, it decreases the likelihood that early puberty has a medical cause.

\subsection{Hormones in Milk and Meats}

Various other theories to explain precocious puberty exist, but research has yet to pinpoint them or they have been discounted. One theory that early puberty was caused from added hormones in milk and meats has been unproven [16]. In the 1990's, the artificial bovine growth hormone, rBGH, was thought by some to be a stimulating factor but this is a protein hormone produced in cattle and is destroyed in human digestion. Additionally, rBGH is not a steroid hormone like estrogen.

\subsection{Environmental Factors}

Another theory concerns environmental factors. Parent et al. [17] found that foreign children migrating to Belgium with adoptive or their own parents, and who exhibited signs of CPP, had the presence of DDT in their blood (plasma), a chemical that could disrupt endocrine function. Their subsequent experimental research demonstrated that DDT caused early maturation of rats [17].

Plastics and insecticides were investigated as a cause of CPP because they break down into chemicals similar to estrogen. Among Puerto Rican girls younger than seven, Colón, Caro, \& Bourdony [18] identified a compelling connection between exposure to phthalates and an increase in breast development.

\subsection{Childhood Obesity}

Of all the projected theories about the cause of precocious puberty, many researchers are finding that childhood obesity is highly related. A study assessing sexual maturity among children with normal and elevated body mass index (BMI) found less than 5\% occurrence in children with normal BMI and non-Hispanic white females [19]. Percentages, however, were higher in Mexican American girls and non-Hispanic black females. Kaplowitz [20] reviewed several cross-sectional studies (Girls Health Enrichment Multi-site Studies, Bogalusa Heart Study, and the NHANES III) that examined the relationship of childhood obesity and early pubertal development in girls. All suggested a relationship between increased BMI and body fat to early menarche, pubic hair, and breast development. Interestingly, obesity in boys was linked to later pubertal development rather than early pubertal development. In another study, obesity was positively associated to early sexual development in girls but, in boys, obesity was associated negatively with sexual maturity [21]. A higher percent of body fat in girls at age 5 predicts that they will experience earlier pubertal development by the time they are 9 years of age [1]. Puberty requires the body to have a certain weight and fat distribution. Young women who are gymnasts and ballerinas have low weight and puberty is often delayed. Children who are overweight or obese have high levels of the protein leptin that can stimulate the release of the three main hormones in puberty: hypothalamic gonad- 
otropin-releasing hormone, LH, and FSH. Lee, Kulin and Guo [10] found that the rate of increase in body metabolism index (BMI) from age 3 - 6 years was positively associated with an earlier onset of puberty.

On the other hand, Slyper's [14] findings, previously identified among medical causes, excluded obesity as a factor related to early puberty in African American girls and boys. He theorizes that hyperinsulinaemia and insulin resistance are more strongly linked to early pubertal development than obesity. Hyperinsulinaemia is the presence of higher than normal levels of insulin in the blood in order to control blood sugar. It occurs because of insulin resistance in which the pancreas produces more insulin to compensate and control blood sugar.

Thus far, the pathology and several possible explanations for precocious puberty have been explored. The next section describes the signs that a young boy or girl may be experiencing early puberty.

\section{SIGNS OF PRECOCIOUS PUBERTY}

According to Kaplowitz [2-4,20], in girls, breast enlargement is seen first. It may begin by occurring only on one breast. The breast diameter increases, the areola darkens and thickens and the nipple becomes more prominent. A doctor's examination should be able to determine if the enlargement is due to fat (which can mimic true breast tissue) or to more specific breast tissue. Pubic and axillary (underarm) hair may appear before breast development, at about the same time, or well after the appearance of breast tissue. If the clitoris appears large, it could indicate significant androgen (male hormone) excess. The color of the vaginal mucosa may go from deepred color in prepubertal girls to moist pastel-pink. Some children experience a mild form of acne, but if a child experiences a rapid onset of severe acne, it could be the result of an androgen-excess disorder [2-4,20].

In boys, the first signs are testicular enlargement, which is due to an increased production of FSH that results in increased stimulation of testosterone. The enlargement could be so slight that even the parents don't notice it. About a year later, the male child will experience penis growth, pubic hair growth, and reddening and thinning of the scrotum. Later, the child may acquire acne, voice change, and facial hair growth [2-4,20]. In both boys and girls, adult body odor may be observed. Along with these early puberty signs come many problems.

\section{PROBLEMS ASSOCIATED WITH PRECOCIOUS PUBERTY}

One major problem as a result of precocious puberty is that early growth spurts stop further growth. The brain signals the bones that growing time is over and children, therefore, instead of growing tall, will remain, on the average, shorter than their peers [2-4]. If caught early enough, there are medications that could help.

Other problems are psychosocial. Precocious puberty brings great concern to others besides parents: the child, their peers, teachers, school nurses and counselors. Studies of young girls indicate that those who develop early are more likely to be depressed, aggressive, socially withdrawn, and moody [22,23]. Girls under age 10 are not mentally prepared for early menstruation and other pubertal development. Both genders may feel isolated from their peers and develop social and emotional problems such as low self-esteem, depression and substance abuse. Some studies indicate that teen-age girls who develop early have more problems in school and are more likely to engage in risky behaviors such as becoming sexually active, smoking and using alcohol and drugs [24-26]. Children who experience early puberty are expected to act and dress the age they look which can lead to earlier sexual experiences. Girls who develop early could also be "coerced” into sexually advanced relationships because they have not yet learned the self-confidence to ward off aggressive, sexual pressure.

\section{WHEN TO SEEK MEDICAL ADVICE}

Medical advice should be sought from a pediatric endocrinologist if there is development of breast growth and first period in girls before age 8 and before age 9 in boys; and if they show signs of enlarged testicles and penis, facial hair, and deepening voice. Other signs of early puberty in both girls and boys that require medical advice are pubic or underarm hair, rapid growth, and acne and adult body odor [27].

\section{DIAGNOSIS}

Diagnosis will include blood tests to measure hormone levels. X-rays of the child's hand and wrist should determine the child's bone age and will show if the bones are growing too quickly. There are also specific procedures used to determine if early puberty is peripheral or central. Magnetic resonance imaging (MRI) of the brain may be done to assess if any brain abnormalities are causing the early start of puberty [28].

\section{TREATMENT}

If the diagnosis is CPC, GnRH analogue therapy is given. This requires a monthly injection of a medication, such as leuprolide, which stops the HPG axis and delays further development [12,28]. The child stays on this medication until he or she reaches the normal age of puberty. Once he or she stops receiving the medication, the process of puberty begins again. If the diagnosis is PPB and is due to an underlying medical condition, that con- 
dition is treated. For example, if it's a tumor, it may need to be surgically removed [28].

Normal adult height can be achieved in most cases if treatment is started before bone maturation is too advanced ( $>12 \mathrm{y}$ in girls, $>13 \mathrm{y}$ in boys) and if good gonadal suppression is maintained for several years. Treatment allows growth to continue while dramatically slowing the rate of bone maturation $[28,29]$.

\section{SUPPORT STRATEGIES}

One of the first contacts for supporting children with potential precocious puberty is the school. Teachers should be informed about the signs of precocious puberty and should contact parents and a school nurse who can become the conduit to obtain needed medical advice. If the diagnosis of precocious puberty is due to the child being overweight or obese, the school nurse can advise parents and, with the help of a nutritionist, plan a weight reduction program.

Both the child and parents may need to seek counseling that could help the family better understand and handle the emotions, issues and challenges that accompany precocious puberty. If schools have a good counseling program, this is a time that school counselors could be of great use in helping parents and their child navigate through some troubling years.

When a child begins exhibiting signs of normal or early pubertal development, outside help for parents is easily accessed on the Internet. For example, some YouTube puberty videos [30] (at

http://www.youtube.com/watch?v=FTc_R24CIU0\&featu re=related) are animated and some are created and developed by teens. Parents could preview them and select those that they could watch with their children. An example of one video is titled, "Creating a puberty survival kit for your daughter". Another video is titled, "Girls and early puberty". For the boys, a good one is "Nick goes through puberty".

Both young girls and boys who experience precocious puberty need to be empowered to develop a good and healthful feeling about their own bodies. All who work with young girls and boys need to help correct body image misperceptions. Teachers, guidance counselors, school nurses, and health teachers must work together to address psychosocial and behavioral risks that tend to be associated with early sexual development. At this critical time it is important that as children move through early puberty, and beyond, that they should be encouraged to engage in opportunities for pro-social involvement such as membership in a community or civic organizations such as Boys and Girls Clubs, Big Brothers/Big Sisters, and Boy or Girl Scouts.

\section{CONCLUSION}

Precocious puberty can be a troubling time for children and their parents, but fortunately there is medical treatment to stop further physical pubertal development, and there are several forms of support strategies available to help both the child and parents. Most importantly, parents, school nurses, and teachers should become knowledgeable about precocious puberty so that treatment and support can be given in the early stages.

\section{REFERENCES}

[1] Davison, K., Birch, L. and Susman, E. (2003) Percent body fat at age 5 predicts earlier pubertal development among girls at age 9. Pediatrics, 11, 815-821. http://dx.doi.org/10.1542/peds.111.4.815

[2] Kaplowitz, P. (2002) Precocious puberty in girls and the risk of a central nervous system abnormality: The elusive search for diagnostic certainty. Pediatrics, 109, 139-141. http://www.pediatrics.org/cgi/content/full/109/1/139.

[3] Kaplowitz, P. (2004) Clinical characteristics of 104 children referred for evaluation of precocious puberty. The Journal of Clinical Endocrinology \& Metabolism, 89, 3644-3650. http://dx.doi.org/10.1210/jc.2003-031532

[4] Kaplowitz, P. (2004) Precocious puberty: Update on secular trends, definitions, diagnosis, and treatment. Advances in Pediatrics, 51, 37-62.

[5] Marshall, W. and Tanner, J. (1969) Variations in pattern of pubertal changes in girls. Archives of Disease in Childhood, 44, 291-303. http://dx.doi.org/10.1136/adc.44.235.291

[6] Marshall, W. and Tanner, J. (1970) Variations in the pattern of pubertal changes in boys. Archives of Disease in Childhood, 45, 13-23.

[7] Herman-Giddens, M., Slora, E., Hasemeier, C., et al. (1997) Secondary sexual characteristics and menses in young girls seen in office practice: A study from the Pediatric Research in Office Settings network. Pediatrics, 99, 505-512.

[8] Centers for Disease Control and Prevention and National Center for Health Statistics (2013) National Health and Nutrition Examination Survey.

http://www.cdc.gov/nchs/nhanes/nhanes_questionnaires.h $\underline{\mathrm{tm}}$

[9] Biro, F., Galvez, M., Wolff, M., et al. (2010) Pubertal assessment method and baseline characteristics in a mixed longitudinal study of girls. Pediatrics, 126, 583590. http://dx.doi.org/10.1542/peds.2009-3079

[10] Lee, P.A., Kulin, H.E. and Guo, S.S. (2001) Age of puberty among girls and the diagnosis of precocious puberty. Pediatrics, 107, 1493.

http://dx.doi.org/10.1542/peds.107.6.1493 http://pediatrics.aappublications.org/cgi/content/full/107/ $\underline{6 / 1493}$

[11] Faizah, M., Zuharis, A., Zulfiqar, M., et al. (2012) Precocious puberty in children: A review of imaging findings. 
Biomedical Imaging and Intervention Journal, 8, 1-8.

[12] Mayo Clinic Staff (2011) Precocious puberty. http://www.mayoclinic.com/health/precocious-puberty/D $\underline{\mathrm{S} 00883}$

[13] Kakarla, N. and Bradshaw, K. (2003) Disorders of pubertal development: Precocious puberty. Seminars in Reproductive Medicine, 21, 339-351. http://dx.doi.org/10.1055/s-2004-815590

[14] Slyper, A. (2006) The pubertal timing controversy in the USA, and a review of possible causative factors for the advance in timing of onset of puberty. Clinical Endocrinology, 65, 1-8.

http://dx.doi.org/10.1111/j.1365-2265.2006.02539.x

[15] Phillip, M. and Lazar, L. (2005) Precocious puberty: Growth and genetics. Hormone Research, 64, 56-61. http://dx.doi.org/10.1159/000087760

[16] Styne D. (2011) Puberty. In: Gardner, D.G. and Shoback, D., Eds., Greenspan's Basic and Clinical Endocrinology 9th Edition, McGraw-Hill Medical, Chicago, 527-549.

[17] Parent, A., Rasier, G., Bourguignon, J., et al. (2005) Early onset of puberty: Tracking Genetic and Environmental Factors. Hormone Research, 64, 41-47. http://dx.doi.org/10.1159/000087753

[18] Colón, I., Caro, D., Bourdony, C., et al. (2000) Identification of phthalate esters in the serum of young Puerto Rican girls with premature breast development. Environmental Health Perspectives, 108, 895-900. http://dx.doi.org/10.1289/ehp.00108895

[19] Rosenfield, R., Lipton, R. and Drum, M. (2009) Thelarch, pubarche, and menarche attainment in children with normal and elevated body mass index. Pediatrics, 123, 84-86. http://dx.doi.org/10.1542/peds.2008-0146 http://pediatrics.aappublications.org/content/123/1/84.sho rt

[20] Kaplowitz, P. (2008) Link between body fat and the timing of puberty. Pediatrics, 121, S208-S217. http://dx.doi.org/10.1542/peds.2007-1813F http://www.pediatrics.org/cgi/content/full/121/Supplemen t 3/208
[21] Wang, Y. (2002) Is obesity associated with early sexual maturation? A comparison of the association in American boys versus girls. Pediatrics, 110, 903. http://dx.doi.org/10.1542/peds.110.5.903

[22] Sonis, W., Comite, F., Klein, R., et al. (1985) Behavior problems and social competence in girls with true precocious puberty. Journal of Pediatrics, 106, 156-160. http://dx.doi.org/10.1016/S0022-3476(85)80489-3

[23] Trembley, L. and Frigon, J. (2005) Precocious puberty in adolescent girls: A biomarker of later psychosocial adjustment problems. Child Psychiatry \& Human Development, 36, 73-94. http://dx.doi.org/10.1007/s10578-004-3489-2

[24] Phinney, V. and Jensen, L. (1990) The relationship between early development and psychosexual behaviors in adolescent females. Adolesence, 25, 321-332.

[25] Ge, X., Conger, R. and Elder, G. (1996) Coming of age too early: Pubertal influences n girls' vulnerability to psychological distress. Child Development, 67, 3386-3400. http://dx.doi.org/10.2307/1131784

[26] Graber, J., Lewinsohn, P., Seeley, J., et al. (1997) Is psychopathology associated with the timing of pubertal development? Journal of the American Academy of Child and Adolescent Psychiatry, 36, 1768-1776.

[27] US Department Health and Human Services, HRSA, Maternal and Child Health Bureau (2009). Adolescent physical development. http://depts.washington.edu/growth/module7/text/ref.htm

[28] Antoniazzi, F. and Zamboni, G. (2004) Central precocious puberty: Current treatment options. Pediatric Drugs, 6, 211-231. http://dx.doi.org/10.2165/00148581-200406040-00002

[29] Leung, A. and McArthur, R. (1991) Recent advances in the treatment of isosexual precocious puberty. Canadian Family Physician, 37, 2597-2604.

[30] YouTube Puberty videos. http://www.youtube.com/watch?v=FTc_R24CIU0\&feature =related 